\title{
EXORCISING THE ANGEL OF THE HOUSE IN PAULA VOGEL'S HOW I LEARNED TO DRIVE
}

Amany Mahmoud Mohamed Abdel-Samad El-Sawy

Lecturer in the Department of English Language and literature,

Faculty of Education,

Alexandria University 


$$
2
$$




\title{
Exorcising the Angel of the House in Paula Vogel's How I Learned to Drive
}

\author{
Amany El-Sawy \\ Lecturer in the Department of English Language and literature, \\ Faculty of Education, Alexandria University
}

\begin{abstract}
Paula Vogel breaks the mold of portrayals of women in literature and views the "angel in the house" as a harmful image for women to emulate. Thus this paper tries to show how Vogel in How I Learned to Drive paints a brutally raw and troubling picture of pedophilia and illustrates the interconnectedness of sex, sexuality and power dynamics of a relationship that breaks generational boundaries. Vogel breaks away from traditional feminist portrayals of sexual abuse in that she deconstructs the simplistic power binary of 'evil abuser' versus 'innocent victim.' Instead, she dramatizes the complexity of power dynamics by portraying the abuser as a caring yet coercive individual. Along the same lines, Vogel portrays the abused as a manipulated, yet sometimes manipulating and sometimes consensual participant in the relationship. I use Michel Foucault's theory on the interrelationship between sexuality and power as well as his theory of resistant subjectivity. Moreover, I apply theories by feminists, such as Gayle Rubin, who use Foucault's study of power dynamics to fund their own scholarship on gender and sexuality.
\end{abstract}

\section{Keywords:}

Foucauldian/feminism, sexuality, power dynamics , pedophilia, resistant subjectivity 


\section{طرد ملاك البيت في مسرحية باولا فوجيل}

\section{"كيف تعلمت ان اقود" \\ أماني محمود الصاوي}

مدرس بقسم اللغة الانجليزية و أدابها ـ كلية التربية ـ جامعة الاسكندرية

\section{ملخص البحث}

حطمت "باو لا فوجل" قولبة النساء في الادب واعتبرت فكرة ملاك البيت فكرة

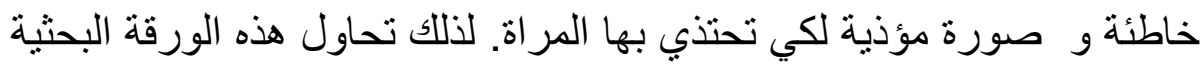

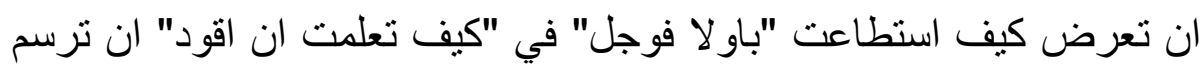

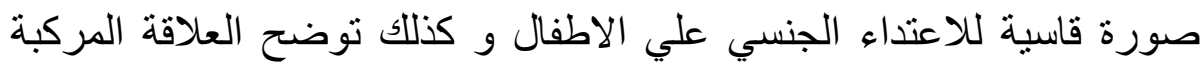

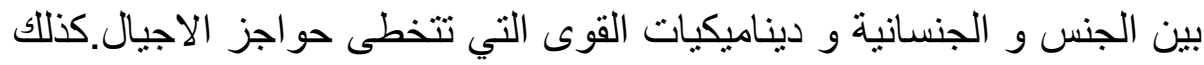

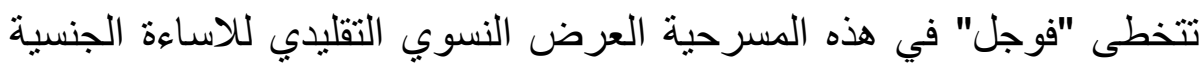

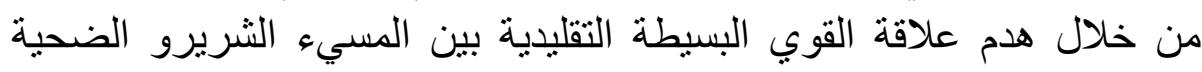

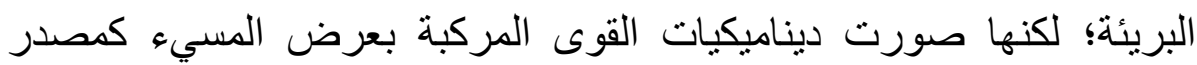

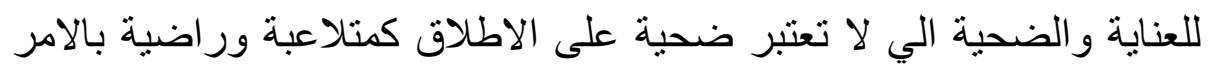

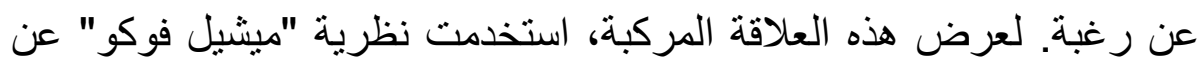

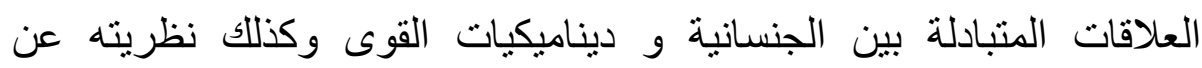
المقاومة الذاتية. بالاضافة الى تطبيق نظريات بعض من النئن النقاد النسويين مثل

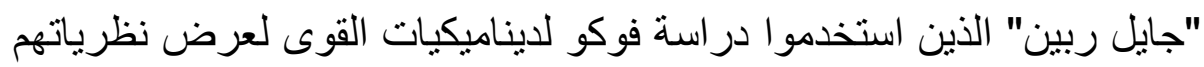
عن الجنسانية والنوع. 


\section{EXORCISING THE ANGEL OF THE HOUSE IN PAULA VOGEL'S HOW I LEARNED TO DRIVE}

\section{Introduction}

Paula Vogel (1951- ) is an American playwright and university professor. She received the 1988 Pulitzer Prize for her Play How I Learned to Drive. As a twentieth/twenty first century feminist playwright, Vogel bursts out historical, social, and political "truths" about power, sex, and corporeal identities. She creates an innovative feminist aesthetic that subverts dominant culture ideology and challenges the patriarchal structures that subordinate women as secondclass citizens. Vogel explores the shifting balance of power between men and women, women's resistance to the powerless label of "victim," as well as the effects of patriarchal power on both sexes. Her plays expose the alarming prevalence of psychological and sexual abuse against women. She critically explores traditional constructions of women's corporeality and celebrates radical representations of the female body with the objective of subverting existing gender, social, and moral paradigms. Vogel is a valuable voice in feminist dramatic discourse because she transgresses an idealized portrayal of women through her diverse dramatizations of female characters, illustrating the harsh realities of women's continued subordinate position in society.

Vogel dramatizes disturbing representations and raises unsettling and painful questions about gender and power. She aims not merely to shock her audiences but to affect her spectators intellectually and viscerally to enact social change. Vogel disallows her audience to distance themselves 
from her personae in terms of moral values or claim that certain issues do not affect them. The social ills Vogel dramatizes are not problems for "other" people to face, but they are unresolved issues that need to be immediately addressed. She wants each audience member to ask, how do one's thoughts and actions, both overtly and covertly, contribute to the cloud of misogyny that pollutes society? How is one complicit in reinforcing attitudes that contribute to the subordination and abuse of women?

Thus this paper tries to show how Vogel in How I Learned to Drive paints a brutally raw and troubling picture of pedophilia and illustrates the interconnectedness of sex, sexuality and power dynamics of a relationship that breaks generational boundaries. Vogel breaks away from traditional feminist portrayals of sexual abuse in that she deconstructs the simplistic power binary of 'evil abuser' versus 'innocent victim.' Instead, she dramatizes the complexity of power dynamics by portraying the abuser as a caring yet coercive individual. Along the same lines, Vogel portrays the abused as a manipulated, yet sometimes manipulating and sometimes consensual participant in the relationship. Michel Foucault's theory on the interrelationship between sexuality and power as well as his theory of resistant subjectivity are relevant to my reading of How I Learned to Drive.

Foucault's philosophy of power relations has given feminist theory another angle to realize women's subordination in society. Like Foucault, Foucauldian/feminists seek to reposition power away from ideological perspectives that situate women as onedimensional victims who are dominated by men. While Foucault supplies feminist theory with one theory on power, some feminists explore the limitations of Foucault's ideas 
when applied to women. Still, a Foucauldian/feminist lens provides an appropriate springboard for the discussion of How I Learned to Drive due to his emphasis on power, resistant subjectivity, and sexuality.

\section{Foucault's Power Theory and the Empowered Subject}

In The History of Sexuality, Foucault explores sexual discourses within the social environment of the early eighteenth century, observing that during this period, discussions of sexuality emerged in political and scientific spheres. The eighteenth century did not define sex solely on the basis of sensation and pleasure or law and taboo but also in terms of truth/falsehood discourse. Foucault highlights that the "truth of sex became something fundamental, useful, or dangerous, precious or formidable: in short, that sex was constituted as a problem of truth” (History 57). Foucault argues that while the eighteenth century may have introduced the "truths" and "falsehoods" of sex, this discourse still predominates sexual dialogues in contemporary society (History 59).

As Foucault observes, the dominant culture continues to enact surveillance over sexual practices through the authority of juridical power. In his words, "the representation of power has remained under the spell of monarchy. In political thought and analysis, we still have not cut off the head of the king" (History 89). According to Foucault, a "juridico-discursive" model of power solely centers on rules of law and the operation of taboos. Juridical power situates sex in a binary system of permitted and prohibited behavior (History 83). Such power represses sex and supports the notion that law should constitute desire. Repressive power is defined: 
[I]n a strangely restrictive way, in that, to begin with, this power is poor in resources, sparing of its methods, monotonous in the tactics it utilizes, incapable of invention, and seemingly doomed always to repeat itself. Further, it is a power that only has the force of the negative on its side, a power to say no; in no condition to produce, capable only of posting limits, it is basically anti-energy. (History 85 )

Foucault asserts that an analytics of power must break away from evaluating power discourses in terms of the law and offers his own non-repressive model. For Foucault, power does not belong to one single individual source of control (i.e. the dominant class) or center around a universal system of authority. Rather, power is accessible to all subjects because of the presence of resistance in power relations. The notion of resistance is crucial to Foucault's conceptualization of power. He notes that "where there is power, there is resistance, and yet, or rather consequently, this resistance is never in a position of exteriority in relation to power" (History 95).

Foucault's theories of power and resistant subjectivity prove valuable in the explorations on How I Learned to Drive, allowing me to look at Li'l Bit, the main female character in the play, as an empowered subject rather than as a traumatized victim. Vogel personifies Li'l Bit as a strongwilled young woman in a resistant power struggle with her uncle Peck, rather than simply as a victim in an inescapable, repressive situation. Li'l Bit asserts agency as an individual, violating the expectations of those who aim to keep her in a powerless state. Therefore, this paper attempts to answer the following questions: How do the power dynamics in How I 
Learned to Drive correspond with the Foucauldian model of power? How does Li'l Bit embody Foucault's notion of the resistant subject and, thereby, permit an interpretation of her as empowered subject rather than victim of abuse?

Furthermore, Foucault's analysis of sexuality helps to present Li'l Bit and Peck's relationship beyond a repressive power discourse of abuse. Through the portrayal of Li'l Bit and Peck's bond, Vogel demonstrates how complex the issues of children's sexuality and pedophilia can be. Rather than make moral judgments about Li'l Bit and Peck's relationship, she illustrates the slippery border between consent and abuse among adults and youths. If, as Foucault asserts, juridical law should not establish the definition of a consensual sexual relationship, how do we measure what constitutes consent versus abuse between adults and children? Thus the paper explores how a Foucauldian/feminist view of sexuality changes our view about the power dynamics between Li'l Bit and Peck and provides a new understanding of Vogel's portrayal of an incestuous and intergenerational relationship.

\section{Context, Form and Reception of How I Learned to Drive}

Vogel's How I Learned to Drive has received several awards, including the 1998 Pulitzer Prize for Drama, the Obie Award for Playwriting, the New York Drama Critics' Circle Best Play Award, the Drama Desk Award, and the Outer Critics' Circle Award. How I Learned to Drive has been produced over sixty-five times in regional theatres across the country, making it the most popularly produced new play in America in 1999. While Vogel intended her play about sexual abuse to be a critique of society's sexualization of children, the reviews of the play suggest a different interpretation. The play has been praised for its 
depiction of sexual abuse as a love story and its lack, of social critique. Nevertheless, when presented in a society in which confusion about sexual abuse proliferates, Vogel's ambiguity lends itself to the hazardous outcomes of sexual abuse.

Vogel utilizes a non-linear structure in How I Learned to Drive to tell a story about child sexual abuse and incest. The play is written in a memory form as a 35-year old "Li'l Bit" looks back on the sexual abuse she endured from her uncle Peck. In a series of non linear scenes, Li'l Bit's memories unfold backwards from ages 17 to 12, then jump forward to 18 and then backwards to 11. Li'l Bit's memories of adulthood experiences after the abuse are interspersed throughout the childhood memories. Li'l Bit in all stages of her life is played by one actor. Besides Li'l Bit, the only other character who has a stable role throughout the play is Uncle Peck. Vogel also uses a Greek chorus consisting of two women and one man to play other roles in the play. The male Greek chorus member plays the grandfather, a waiter, and various adolescent male roles in the play. The teenage Greek chorus member plays the grandmother and one of Li'l Bit's peers at school. The female Greek chorus plays the mother, Aunt Mary, and another one of Li'l Bit's friends in the play. The chorus also provides transitions from one scene to another. Vogel introduces each scene in the play with titles in the form of driving instructions which she has indicated are to be divided up between members of the Greek chorus and spoken with a flat expression, as in driver education films. The instructions are generally simple, such as "you and the reverse gear," however for some scenes, more elaborate instructions are given, like "Good defensive driving involves mental and physical preparation. Are you 
prepared?” Occasionally, scenes are framed with driving instructions such as "Are you prepared?" and, at the end of the scene, "Were you prepared?" These kinds of "instructions" serve to comment on the scenes between them.

In an August 1998 interview with American Repertory Theatre's Arthur Holmberg, Vogel discussed her political purpose behind the play. Citing JonBenét Ramsey ${ }^{1}$ as an example, Vogel said that the play was "a way of looking on a microcosmic level at how this culture sexualizes children" (2). Vogel noted how society sexualizes children at an early age through various mediums including advertisements, entertainment, and beauty pageants. According to Vogel, "children's bodies are sexualized all the way down from Madison Avenue to the wealthy suburb of Denver where the Ramseys lived" (2).

Many feminist writers and psychologists have begun to express concern over the sexualization of children which Vogel observes. The issue has been brought up in the last decade in books on feminism, child sexual abuse, female sexuality, and adolescent sexuality. Both Susan Faludi in Backlash (1991) and Naomi Wolf in The Beauty Myth (1991) commented on the prevalence of the sexualization of female children. Judith Daniluk in Women's Sexuality Across the Life Span observes that "[i]t is becoming common for children of 9 to 13 years to be dressed up in advertisements to look like sensual, adult, women” (115).

\footnotetext{
${ }^{1}$ JonBenét Ramsey was a 6-year-old beauty queen who was found murdered in her Boulder, Colorado, home on December 26, 1996
} 
According to E. Sue Blume in Secret Survivors: Uncovering Incest and Its Aftereffects in Women, "we dress 7-year-old models to look 15, and 15-year old models to look 21" (209). Moreover, Chris Bagley in Children, Sex, and Social Policy believes that "adolescent sexuality in its various forms of erotic media and erotic display, seem to be here to stay” (43-4).

From a feminist perspective on incest, Vogel's choice to illustrate the sexualization of children through an incestual relationship makes perfect sense. Christine Courtois highlights that Louise Armstrong, author of Rocking the Cradle of Sexual Politics, connects the sexualization of children directly to incest. A feminist analysis of incest looks at the ways society promotes "the development of incest" (Courtois 119). Feminist points of view such as Armstrong's assert that "men are conditioned into roles of power and domination with regard to females, who are conditioned to be passive and dependant" (Courtois 119). In the 1970s, many feminists began speaking out about child sexual abuse (including incest) along with the discussion of rape and other acts of violence against women. According to Courtois, feminists began trying to dismantle incest myths which implied that the victim seduced the perpetrator and that the mother of the victim was more responsible for the abuse than the actual perpetrator (Courtois 119). In understanding this perspective, Vogel's subject of incest seems like the perfect way to illustrate how children are sexualized in our society.

The layout Vogel utlizes in the play also seems to fit a feminist political goal. Vogel's play is similar to a Brechtian form in its use of a non-linear plot and titled episodes. Many feminist theatre theorists and critics have advocated Brecht's 
structure as being an ideal form for feminist theatre. In The Feminist Spectator as Critic, Jill Dolan gives a concise discussion explaining the feminist support of a Brechtian format. Dolan asserts that Brecht's framework encourages audiences to think about the "relationships played out" in a play and to question what might otherwise appear to be "normal" (The Feminist Spectator 106). This approach contrasts with realism, which Dolan suggests "imposes a conservative sense of order by delivering its ideology as normative" (106). A Brechtian framework "discards linear narrative, presenting instead a series of episodes heralded by titles that unsettle the spectator's expectation of suspense" (107). Despite Vogel's political goal and the Brechtian format of her play, the reviews for How I Learned to Drive do not recognize the play's use of such techniques to critique incest from a feminist perspective.

Despite the play's subject matter, How I Learned to Drive has repeatedly been called a "love story" by theatre critics all across America. The abuse Li'l Bit endures has been described as "empowering" and "beneficial" in the midst of what appears to be her otherwise rotten family life. Some reviewers have even gone so far as to describe the victim as a "seductress." Reviewers implied that Peck's sexual abuse of Li'l Bit appeared less harmful than the harassment she received from her family, particularly her mother. Stefan Kanfer of The New Leader discussed the damage Li'l Bit's mother caused her, rather than Peck's abuse. Kanfer further confirmed incest myths by calling Li'l Bit a "seductress" and seemed to accept Peck's affection for Li'l Bit as "love" (2-3). Dolan, who reviewed the play for Theatre Journal, praised the play for its non-linear layout, which she believed depicted the "complexity" of the 
relationship. Dolan felt that Peck's attraction towards and objectification of Li'l Bit empowered her in the midst of a bad family life ("How I Learned to Drive" 127).

When the play moved from the Vineyard Theatre to the Century Theatre, the reviewers echoed much of the previously expressed praise for the show and called the play a "love story." Laurie Stone of The Nation reduced the sexual abuse in the play to "a lousy deal" and praised the play for suggesting that Li'l Bit controlled Peck and "like[d] the power" (2) . Robert Brustein of The New Republic wrote that the play is "neither a polemical play nor a feminist tract. Rather, it is a strange, exotic love story" (Brustein 27). Dick Scanlan noted the "seductive" victim and complimented the play for being "steeped in nostalgia and forgiveness" (2). Scanlan felt that Peck was "uncontrollably attracted to and eventually in love with Li'l Bit” (1).

Interviews with Vogel on How I Learned to Drive reveal that some of her ideas behind the play may have contradicted her original goal of illustrating how our society sexualizes children. Vogel says the play is not really about abuse but is ... about healing, forgiving, and moving on" (Farnsworth 2). Vogel has also mentioned that she wants to "seduce" the audience and see if they will allow themselves to be aroused by Uncle Peck (Heilpern 135). Vogel feels that the most important aspect of the play is that the audience "come[s] out loving Uncle Peck," the perpetrator (Farnsworth 2). In contrast to her political goal of illustrating the way society sexualizes children, Vogel seems to be romanticizing abuse.

\section{The Dramatization of the Gifts that Hurt and Empower}

Vogel shatters traditional portrayals of incest and pedophilia and, instead, creates a radical dramatization that 
neither condemns nor sentimentalizes the issues. Vogel, according to Christopher Bigsby, portrays a story of abuse with moral ambivalence and shifting patterns of power (319). In the play, Peck molests Li'l Bit for nearly seven years, but Li’l Bit is not a stereotypical victim. Vogel resists the "After School Special” angle to the subject of pedophilia by dramatizing Li'l Bit as a strong character who grows from her experiences, rather than as a weak, passive female who languishes in a static state of powerlessness. Vogel argues that thinking in terms of a victim-based paradigm "causes almost as much trauma as the original abuse" (Farnsworth 3). Vogel "hate[s] the word victim" because she views it as a "buzz word people use these days ... We're all victims just by virtue of being alive" (Drukman 6). In an interview with Arthur Holmberg Vogel says,

We are now living in a culture of victimization, and great harm can be inflicted by wellintentioned therapists, social workers, and talk show hosts who encourage people to dwell in their identity as victim. Without denying or forgetting the original pain, I wanted to write about the great gifts that can also be inside that box of abuse. My play dramatizes the gifts we receive from the people who hurt us. (3)

As Li'l Bit grows up, she receives the gifts of self-worth and survival from Peck, who becomes her mentor and primary emotional support. She learns to "drive" a metaphor of control and autonomy. Peck instills strength in Li'l Bit that allows her to reject his advances, to separate herself from him, and ultimately be able to move on with her life (Holmberg 3). 
Li'l Bit's resistance of her uncle's manipulative sexual abuse constitutes a primary illustration of the complex power struggles dramatized in How I Learned to Drive. Vogel heightens the presence of resistance in her play, de-emphasizing a discourse of victimization. Employing a Foucauldian model of power and sexuality, I explore Vogel's use of resistance and her rejection of victimization to look at Vogel's radical and controversial view of child abuse. Foucault avoids a discourse of victimization by viewing power dynamics as a series of struggles between the resistant subject and the dominant one. In The History of Sexuality, he demonstrates that power must exist in the presence of resistance (95). Foucault argues that "points of resistance are present everywhere in the power network. Hence there is no single locus of great Refusal, no soul of revolt, source of all rebellions, or pure law of the revolutionary" (History 96). Power relationships rely on the presence of resistances which manifest themselves in the form of several functions such as the adversary, target or support roles. Foucault's theory of resistant subjectivity is employed to illuminate the complex power roles within How I Learned to Drive, in terms of Li'l Bit's character as a subject of resistance and Peck's position as a member of the dominant class.

\section{Reassurance and Resistance: It's All There in the Driving Lessons}

How I Learned to Drive moves forward and back in time, chronicling Li'l Bit's life from an eleven-year-old girl to a thirty-five-year-old woman. The play opens with Li'l Bit's narration of her recollection of intimate times spent with Peck during her driving lessons. She says, "I am seventeen-years-old, parking off a dark lane with a married 
man on an early summer night" (8). Over the course of seven years, Peck expresses his lust and/or love for Li'l Bit. Ironically, although he imposes himself on her, it is the life lesson of assertiveness that he especially teaches her. On one of their outings together, Peck convinces a doubtful Li'l Bit that he will never touch her when she drives. Peck tells Li'l Bit:

There's something about driving-when you're in control of the car, just you and the machine and the road- that nobody can take from you. A power. I feel more myself in my car than anywhere else. And that's what I want to give you ... You're going to learn to think what the other guy is going to do before he does it. If there's an accident, and ten cars pile up, and people get killed, you're the one who's gonna steer through it, put your foot on the gas if you have to, and be the one to walk away. (50)

Peck seems to warn Li'l Bit against his own sexual advances towards her. Further, Peck's instructions foreshadow the day when Li'l Bit “walks away” from him. Peck teaches Li'l Bit survival skills for the road of life, instilling confidence and a sense of power into Li'l Bit while she is and isn't behind the wheel. In moments where she feels weak and helpless, Li'l Bit uses driving as a means to escape Peck. While driving, Li'l Bit acts self-assured just like her uncle has instructed her to be. In Vogel's words, “[h]e teaches her the importance of herself as an individual and the ability to strategize to protect that. It's all there in the driving lessons. It's abuse simultaneously with a kind of affirmation and reassurance" (Holmberg 3). The radical slipperiness of Li'l Bit and Peck's relationship is evident during the driving lessons. In each 
individual driving scene, Peck shifts fluidly from nurturing his niece's growth as a woman to fulfilling his own sexual desires.

Vogel personifies Li'l Bit and Peck's relationship through the use of driving metaphors. Throughout the play, driving symbolizes both Li'l Bit's vulnerability and her strength. To represent this juxtaposition, Vogel interweaves driver's education voiceovers into the text, conveying subversive messages about the power shifts between Li'l Bit and Peck. One of the voiceovers warns the audience to:

Always check under your car for obstructionsbroken bottles, fallen tree branches, and the bodies of small children. Each year hundreds of children are crushed beneath the wheels of unwary drivers in their own driveways. Children depend on you to watch them. (Vogel 45)

This voiceover points to an issue significant to pedophilia in How I Learned to Drive. Li'l Bit's abusive situation occurs in her "own driveway," or within her family sphere. The circumstances surrounding Li'l Bit's abuse reflect real life statistics. Contrary to popular myths, the majority of pedophiles are not scary strangers, but family members of the abused:

At home and in school, parents and teachers emphasize to children that they should not talk to strangers or accept candy or rides. We picture dirty old men in trench coats ready to flash or snatch our children. Most people do not realize that children who are sexually abused are most likely to be abused by someone they know and trust. (Kinnear 17) 
Vogel portrays Peck as a trustworthy individual, in contrast to traditional stereotypes of child molesters. The playwright dramatizes Peck as a caring, friendly family man with sincere emotions and desires. In doing so, Vogel asks her audience to challenge their preconceptions of such relationships as abusive. In her character descriptions at the beginning of the play, Vogel suggests casting Peck as someone who might play To Kill a Mockingbird's Atticus Finch, an endearing, morally upright and law-abiding citizen of the community. With this casting choice, Vogel challenges the notion of pedophiles as evil, lecherous individuals and creates instead a new face of abuse that resembles the "All American," nice, next-door neighbor. Vogel directs her audience to consider the issue of pedophilia as one that is close to home.

Furthermore, the driver's education announcement also illustrates the vast difference in power between children and adults. The picture of small vulnerable children being "crushed" stands in sharp contrast to the powerful and dangerous force of a car's wheels, or an adult abuser. In terms of his power as a man and an adult, Peck purposefully uses his authoritative privileges to take advantage of Li'l Bit's age and gender and initiate an intimate relationship with his niece.

Power Dynamics and Autonomy as Self Defense

\section{$\frac{\text { Mechanisms }}{\text { Power }}$}

Power relations are deliberate and calculated according to Foucault. In his words, "there is no power that is exercised without a series of aims and objectives" (History 95). Peck enacts power over Li'l Bit with a deliberate objective to control Li'l Bit's body; however, Peck does not always make his calculated aims overtly 
obvious to Li'l Bit. During one of Li'l Bit's driving lessons, Peck's tutorial reveals his latent intentions. Referring to the car, Peck instructs Li'l Bit to "[t]reat her with respect ... when you close your eyes ... think of someone who responds to your touch- someone who performs just for you and gives you what you ask for" (Vogel 51). Peck desires to manipulate Li'l Bit in the same way he takes command of his car. However, he fails to account for her agency, and unlike the car, Li'l Bit can assert herself.

Still, the power dynamics present in How I Learned to Drive extend beyond Peck's sexual manipulation of his niece. Li'l Bit follows Peck's advice on the importance of assertiveness, protecting herself not only in the car as a driver, but also in relation to her uncle. Li'l Bit exercises resistant power to guard against Peck during situations where she feels vulnerable and uncomfortable in their relationship. Foucault illustrates that power is not only accessible to those in the dominant class. In Herculine Barbin, Foucault compares power dynamics to a battlefield, or a field of complex struggles. The battlefield encompasses all of the social and historical systems which produce various forms of power. Foucault argues that this battlefield is open to all people, not just one individual source of domination (Herculine 208, 224). Moreover, Foucault argues that power dynamics do not exist in "superstructural" positions of prohibitory control, rather struggles of authority play a purposeful and productive role in relations of power (History 94). Foucault argues that power is not an acquisition to be seized or shared. He refutes a binary description of power, in that he does not believe individuals hold onto or allow power to slip away from them. "Power is 
exercised from innumerable points, in the interplay of nonegalitarian and mobile relations" (History 94).

Foucault's model of power enables us to view Li'l Bit as a subject who asserts a purposeful and active position in the dynamic struggles between Peck and herself. One of the driver's education metaphors encapsulates Li'l Bit's use of power as a strategy for protecting herself:

Defensive driving involves defending yourself from hazardous and sudden changes in your automotive environment. By thinking ahead, the defensive driver can adjust to weather, road conditions and road kill. Good defensive driving involves mental and physical preparation. Are you prepared? (Vogel 51)

Li'l Bit first assertively practices her "defensive driving" skills upon passing her driver's test. Peck takes Li'l Bit out to dinner at a coastal inn to celebrate her accomplishment. Despite her age, he buys her enough drinks to leave Li'l Bit drunk, stumbling, and seemingly at the mercy of Peck's lust. In many ways, the balance of power seems heavily weighted in Peck's favor, considering Li'l Bit's state of inebriation. However, Peck shows weakness as he appears anxious about making physical contact with Li'l Bit. As the two sit parked in the car, Peck asks Li'l Bit, "Do you want to go upstairs? Or home" (Vogel 31)?

Control now shifts from Peck to Li’l Bit illustrating the "nonegalitarian and mobile" character of power dynamics. Neither Peck nor Li'l Bit owns power, rather Li'l Bit asserts herself more authoritatively than her uncle in this moment to guard herself against a proposal that makes her feel ill at ease. Li'l Bit's mood changes from playful to serious as she says, “This isn’t right, Uncle Peck ... What 
we're doing. It's wrong. It's very wrong," (Vogel 31) and Li'l Bit takes her uncle aback even more when she declares, "You know. It's not nice to Aunt Mary" (Vogel 31). Li'l Bit's words strike a painful chord with him as he snaps at his niece, "You let me be the judge of what's nice and not nice to my wife" (Vogel 31). Peck's defensive response illustrates the guilt he feels for his infidelity and exposes his feelings of failure and vulnerability. The power dynamics in this scene cannot be adequately analyzed in terms of a binary that simply defines Li'l Bit as empowered and Peck as powerless. In looking at the power struggles between Li'l Bit and Peck, it is important to consider Foucault's argument that individuals do not hold onto power or allow power to slip away from them. The balance of power does not favor Li'l Bit because she seizes authority from Peck. Nor is she empowered because Peck allows his control over her to slip away. Rather, Li'l Bit exercises power as an autonomous individual.

\section{Coercive and Repressive Power of Seduction}

As dramatized in this scene, Vogel delineates the ebb and flow of power between Li'l Bit and Peck. Vogel's representation of power accords with the Foucauldian/feminist model, in that Li'l Bit and Peck's relationship cannot be adequately analyzed solely in terms of repression and domination. Foucauldian/feminists, such as Jana Sawicki and Gayle Rubin, further nuance this distinction as they do not deny the existence of sexual repression, but rather they object to the notion of power as a purely repressive entity. Sawicki notes that Foucault rejects a repressive model of power which he describes as solely forceful. Foucault thinks that "if power were merely repressive, then it would be difficult to explain how it has 
gotten such a grip on us. Why would we continue to obey a purely repressive and coercive form of power?” (Sawicki 21). Sawicki views repressive power as the most frustrated and extreme form of power. According to her, an individual who resorts to a show of force demonstrates his or her lack of power (21). Repressive power certainly exists within the world of Vogel's play in terms of the manipulative and coercive force Peck sometimes uses to seduce Li'l Bit. In most of the scenes of physical intimacy between Li'l Bit and her uncle, Peck controls the flow of actions between them. However, as Li'l Bit grows older, she gradually refuses Peck's physical affection and reliance on her. Bigsby asserts that, "If anything, power seems to reside with the young woman and not the man whose behaviour makes him seem younger than he is, and more dependent” (321). When Peck resorts to manipulative and coercive force, he embodies desperation and demonstrates his lack of control rather than his possession of power.

Despite the significant presence of repressive power, power takes on other less repressive forms during the course of the play. When Li'l Bit goes off to college, she matures and experiences life separate from her uncle, enabling her to strongly question the appropriateness of their union and resist Peck's advances more aggressively. Li'l Bit's power develops; although, she does not enact repressive power like Peck. On Li'l Bit's eighteenth birthday, she asserts full control over her body and well-being. She agrees to meet Peck at a hotel but not to partake in their usual activities together. Li'l Bit seeks to end any contact with Peck after his stalker-like behavior. She says,

You scared the holy crap out of me-sending me that stuff in the mail- 
PECK. They were gifts! I just wanted to give you some little perks your first semester-

L1'L BIT. Well, what the hell were those numbers all about! Forty four days to go-only two more weeks. And then just numbers 69-6867-like some serial killer! (Vogel 75)

Even as she asks, Li'l Bit knows that Peck counted down the days until her birthday in order to legally engage in sexual activity with her. In spite of Li'l Bit's disgust and anger towards him, Peck desperately longs for intimacy with her. Out of desperation he proposes marriage with her. Li'l Bit responds,

What have you been thinking! You are married to my aunt, Uncle Peck. She's my family. You have-you have gone way over the line. Family is family. (Quickly, Li'l Bit flies through the room, gets her coat.) I'm leaving. Now. I am not seeing you. Again. (Peck lies down on the bed for a moment, trying to absorb the terrible news. For a moment, he almost curls into a fetal position.) I'm not coming home for Christmas. You should go home to Aunt Mary. Go home now, Uncle Peck. (Vogel 85)

For the first time in the play, Peck is completely at the mercy of Li'l Bit. This scene marks the pivotal shift in the power dynamics between Peck and Li'l Bit. As Peck struggles to hold onto his niece, he is vulnerable and scared, nearly curling into the fetal position.

The balance of power tips toward Li'l Bit as she breaks away from her uncle since she no longer relies on him for emotional support. For her to move on with her life, she must exploit the very survival skills Peck taught her and 
separate herself from her past. Eventually, Li'l Bit stops seeing Peck because she has matured into adulthood and doesn't need him anymore. Staying emotionally involved with Peck would hinder her newly found adult freedom. Li'l Bit becomes less and less reliant on Peck for some sense of inner strength, and her objectives coalesce around empowering herself rather than fulfilling her uncle's emotional and physical needs. By the play's end she has modified its hold through empowerment.

\section{Witnessing Empowerment and Breaking the Cycle of Abuse}

Vogel dramatizes the damaging effects of child sexual abuse through Li'l Bit's actions as an adult. Li'l Bit experiences significant trauma from her relationship with Peck. As a mature adult, Li'l Bit repeats many of the same problematic choices made by her uncle; she engages in a relationship with an underage boy. Li'l Bit seduces him in a manipulative manner, in an jarringly similar way to what she experienced with Peck while an eleven-year-old girl. She says:

I lay on my back in the dark and I thought about you, Uncle Peck. Oh. Oh-this is the allure. Being older. Being the first. Being the translator, the teacher, the epicure, the already jaded. This is how the giver gets taken. (Vogel 41)

In her affair with the young boy, Li'l Bit replicates, but transposes the gender and power dynamics taught to her by her uncle.

After Li'l Bit breaks off the relationship with Peck, she struggles to function normally in college and at her "dead-end day jobs" (16). Nevertheless, she copes with her 
depression by "Racing in a 1965 Mustang" (21). Out of despair, Li'l Bit admits,

[A]s long as I had gasoline for my car and whiskey for me, the nights would pass. Fully tanked, I would speed past the churches and the trees on the bend, thinking just one notch of the steering wheel would be all it would take, and yet some ... reflex took over. My hands on the wheel in the nine and three o'clock position ... He taught me well. (Vogel 21)

Nevertheless, Peck's driving lessons fuel Li'l Bit's suffering. While her uncle's guidance simultaneously and ironically gives her strength, it allows her to forgive him, and enables her to move on with her life. At the end of the play, driving remains a symbol of power, confidence, and control for both Li'l Bit and Peck. Li'l Bit relays to the audience that Peck fell into deep depression following their breakup and lost his driver's license. This event symbolizes his demise, his emasculation, and his loss of power over his and others' lives. After he loses his license, he loses his wife and ultimately his life. In contrast, Li'l Bit's future holds promise as she "put[s] herself quite literally [and metaphorically] in the driver's seat" (Savran 265). While Peck enacts sexual power over Li'l Bit as a young girl, she does not allow him to keep her powerless for the rest of her life. Li'l Bit overcomes mountainous obstacles through her refusal to remain a victim. She forgives her uncle, but she will certainly never forget him. In the final moment of the play, Li'l Bit drives off in her car with her uncle's memory reflected in her rearview mirror. There Li'l Bit embodies self-empowerment as she speeds away but never quite 
escapes the abuse and pain in her past nor her uncle's image which will always be reflected in and haunt her life.

How I Learned to Drive offers hope for social change; it portrays trauma and female complicity as ugly realities faced by women each day. By witnessing Li'l Bit's experience, audiences are exposed to severity of social ills such as sexism, sexual abuse. According to Vogel, theatre should serve as a sounding board for sociopolitical issues. She says:

I worry that there is no longer a place for audiences to come to a civic space-the theatreto confront the disturbing questions of our time. I remain scared of the dark-scared of our darkness and I seek a communal light in the darkness of our theatres. (Fischlin \& Fortier 233)

Neither sentimental nor didactic, Vogel stages social problems with painful honesty, bringing a new, yet disturbing, light to the issues at hand. Vogel does not provide answers, nor is her outlook always optimistic that societal change will occur and the problems will be solved. At the end of How I Learned to Drive, Li'l Bit may try to break the cycle of abuse, but we do not feel reassured that the social problem of pedophilia is closer to resolution. Her art is not palliative and leads one to ask, why does Vogel project such a pessimistic view of social change? Her aim is to encourage awareness.

Vogel's feminist aesthetic deconstructs women's disempowering experiences. Vogel seduces her audience to empathize on a visceral level with Li'l Bit's struggle and then pushes them out of their comfort zone. The despair we feel at the end of How I Learned to Drive is an anguish that 
motivates us to take social action. She urges consideration of the continued effects of abuse in the absence of effectual socialization. Engaging ourselves with Vogel's play as active rather than passive spectators, she challenges us to ponder and to enact social change that will profit both men and women. Vogel asks us to look in the mirror and see our own internalized misogyny, to revise new voices and gender roles for women, and to rewrite a new history of gender relationships for men and women. The costs of not doing so are too great to ignore.

\section{Conclusion}

How I Learned to Drive illustrates the interconnectedness of sex, sexuality and power dynamics of a relationship that surpasses generational boundaries. Vogel paints a brutally raw and troubling picture of pedophilia. "Vogel has raised the stakes, peeled away the layers of sentimentality and self-deceit, until we are face to face with the thing itself" (Bigsby 325). One of the primary characteristics of Vogel's feminist, radical theatre is her frank portrayal of contentious social problems that are uncomfortable and painful to address. In Vogel's straightforward depiction of pedophilia, power lies at the core of sexual abuse issues. Vogel breaks away from traditional feminist portrayals of sexual abuse in that she deconstructs the simplistic power binary of "evil abuser" versus "innocent victim." Instead, she dramatizes the complexity of power dynamics by portraying the abuser as a caring yet coercive individual. Along the same lines, Vogel portrays the abused as a manipulated, yet sometimes manipulating and sometimes consensual participant in the relationship. 
Vogel constructs a radical view of pedophilia that flies in the face of conventions by refusing to demonize the abuser or vindicate the abused. With this portrayal, Vogel aims not to condone child sexual abuse. Rather, she seeks to push the audience out of their comfort zone, making visible the ugly complexities of an abusive situation. Vogel challenges her audience to question and ponder traditional assumptions about pedophilia. Andrea J. Nouryeh asserts that Vogel dramatizes child sexual abuse as a social issue all individuals should confront and address:

Rather than leaving the theatre reassured, we harbor an unsettling feeling that perhaps we had judged Li'l Bit too hastily, that perhaps we had been too easily taken in by Uncle Peck, and that perhaps we are somehow implicated, not only in her victimization but in the exploitation of all children by adults. (62)

As this quote suggests, Vogel blames the whole of society for the mistreatment of children. Her play illustrates how victims, namely women, are often blamed by their families and others in society for the abuse inflicted upon them. As Li'l Bit's mother says to her daughter before the first incident of abuse, "if anything happens, I hold you responsible" (Vogel 88). Vogel's objective is not to blame women, like Li'l Bit, for the abuse inflicted upon them but to challenge the audience, in so far as they are a representation of society, to work through the difficult questions posed by the play.

How I Learned to Drive poses the question: Why are children sometimes made to feel responsible for actions they are powerless to prevent? Vogel creates a feeling of anguish for us as Li'l Bit's mother lays guilt on her daughter for 
abuse we know is imminent. Vogel strives to stir up sadness and anger in her audience not so that they will feel sorry for Li'l Bit but so that they will try and stop abuse from happening to children like her. Vogel redirects questions about child abuse away from the victim. The play asks, who's really to blame for child sexual abuse? Vogel does not just blame Peck for the abuse inflicted upon Li'l Bit; rather, she implicates Li'l Bit's unloving family who objectifies her body and a society that sexualizes children's bodies from an early age. Further, How I Learned to Drive asks, how do perpetrators of abuse manage to gain the trust of youths in such a manipulative manner? Vogel's play makes us realize that child abusers are not as different from us as we would like to believe. They are not the "other." Pedophiles are seemingly normal like Peck. They need love and contact just like you and me. However, the deleterious effects on Li'l Bit seem to imply that the love and contact is not value-free and that we have to question it. Just as there are similarities between feminist and Foucauldian ideas, there are contradictions among feminist scholars, regarding their interpretation of Foucault's philosophy. Scholars do not seem to be able to easily categorize Foucault as wholly feminist, primarily because of the philosopher's seeming erasure of the female gender in his works.

To conclude, in a fragmented, post-modern society, Vogel breaks the mold of portrayals of women in literature; she views the "angel in the house" as a harmful image for women to emulate. In today's society, women who fit the mold of the feminine ideal are easily attributed to be "normal" and "natural," and women who conform less to this patriarchal model are often deemed mannish and, therefore, "unnatural." Vogel, in How I Learned to Drive, 
creates a female character who disobeys the legacy of the unattainable and oppressive "angel” model. Consequently, she illustrates the destructive and sometimes deadly consequences that befall contemporary women when they fail to live up to the social expectations and standards of behavior for women. For Vogel, these standards and social expectations are, in part, to blame for women's lost sense of autonomy, creativity, and agency. Vogel resurrects these attributes for women through representing strong, autonomous, even subversive women on stage while, offstage she metaphorically "kills" the women who would embody the attributes of "the angel." Vogel exorcises the representation of this "angel" because, in Virginia Woolf's words, "Had I not killed her she would have killed me" ("Professions" 2008). Vogel recognizes that such idealized images hurt women rather than help them transcend their second-class status. 


\section{WORKS CITED}

Bagley, Christopher. Children. Sex, and Social Policy. Brookfield, Vermont: Avebury, 1997.

Bigsby, Christopher. Contemporary American Playwrights.

Cambridge: Cambridge University, 1999

Blume, E. Sue. Secret Survivors: Uncovering Incest and its Aftereffects in Women. New York: Ballantine Books, 1990.

Brustein, Robert. "Homogenized Diversity." The New Republic 217.1 (7 July 1997): pp. 27-29. Online. EBSCOhost. 12 November 2017.

Courtois, Christine. Healing the Incest Wound: Adult Survivors in Therapy. New York: Norton, 1988.

Daniluk, Judith C. Women's Sexuality Across the Life Span: Challenging Myths. Creating Meanings. New York: The Guilford Press, 1998.

Dolan, Jill. The Feminist Spectator as Critic. Ann Arbor: UMI, 1988 .

---. “How I Learned to Drive.” Theatre Journal 50.1 (1998): 127-8.

Drukman, Steven. "A Playwright on the Edge Turns Toward the Middle.” New York Times. 16 March 1997, Late Edition: 6.

Faludi, Susan. Backlash: The Undeclared War Against American Women. Doubleday, 1991.

Farnsworth, Elizabeth. "A Prize-Winning Playwright.” The News Hour with Jim Lehrer Transcript. 16 April (1998): 1-4. 
Fischlin, Daniel and Mark Fortier. "Introduction to Desdemona: A Play about a Handkerchief." Adaptations of Shakespeare: A Critical Anthology of Plays from the Seventeenth Century to the Present. London: Routledge, 2000.

Foucault, Michel. Politics, Philosophy, Culture: Interviews and Other Writings, 1977-1984. Trans. Alan Sheridan. Ed. Lawrence D. Kritzman New York: Routledge, 1988.

---. Herculine Barbin: Being the Recently Discovered Memoirs of a Nineteenth Century French Hermaphrodite. Pantheon: New York, 1980.

---.The History of Sexuality, Volume I: An Introduction. Trans. Robert Hurley. New York: Pantheon, 1978.

Heilpern, John. How Good is David Mamet. Anyway?. New York: Routledge, 2000.

Holmberg, Arthur. "Through the Eyes of Lolita.” (31 August 1998). Online. 4 November. 2017. Available https://americanrepertorytheater.org/inside/articles/thr ough-eyes-lolita

Kanfer, Stefan. 'Li’l bit o' incest.” New Leader 80.11 (30 June 1997). Online. EBSOhost. 11 August 2017.

Kinnear, Karen L. Childhood Sexual Abuse: A Reference Handbook. Santa Barbara: Contemporary World Issues, 1995.

Nouryeh, Andrea J. "Flashing Back: Dramatizing the Trauma of Incest and Child Sexual Abuse." Theatre Symposium: A Journal of the Southeastern Theatre Conference. Tuscaloosa: Southeastern Theatre Conference and the University of Alabama, 1993. 
Rubin, Gayle. "Thinking Sex: Notes for a Radical Theory of the Politics of Sexuality." Pleasure and Danger. Carole S. Vance, Ed. Boston: Routledge, 1984.

Savran, David. The Playwright's Voice: American Dramatists on Memory, Writing and the Politics of Culture. New York: Theatre Communications Group, 1999.

Sawicki, Jana. Disciplining Foucault: Feminism, Power, and the Body. Routledge: New York, 1991.

Scanlan, Dick. "Say Uncle Theater." The Advocate 735.61 (10 June 1997): p. 61.Online. EBSCOhost. 9 December 2017.

Stone, Laurie. “Theatre.” The Nation 265.4 (28 July 1997): 3 pp. Online. EBSCOhost. 10 August 2017.

Vogel, Paula. The Mammary Plays: How I Learned to Drive and The Mineola Twins. New York: Theatre Communications Group, 1998.

Wolf, Naomi. The Beauty Myth . New York: Doubleday, 1991.

Woolf, Virginia. "Professions for Women.” The Norton Anthology of English Literature: Fifth Edition. M. H. Abrams, Ed. New York: W.W. Norton \& Company, 1986. 